\title{
Synthesis of biologically active derivatives of 2-aminobenzothiazole
}

\author{
Larisa V. Zhilitskaya ${ }^{1}{ }^{*}$, Nina O. Yarosh ${ }^{1}$ \\ ${ }^{1}$ Favorsky Irkutsk Institute of Chemistry, Siberian Branch of the Russian Academy of Sciences, \\ 1 Favorsky St., Irkutsk 664033, Russia; \\ e-mail: lara_zhilitskaya@irioch.irk.ru
}

Translated from Khimiya Geterotsiklicheskikh Soedinenii,

Submitted October 27, 2020

2021, 57(4), 369-373

Accepted February 17, 2021

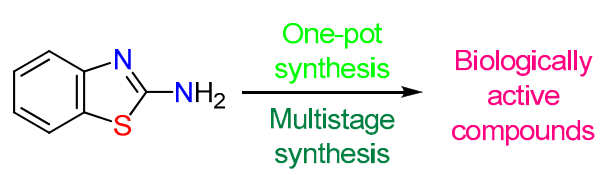

The minireview considers the current trends in the synthesis of some biologically active compounds based on 2-aminobenzothiazole. The presented information covers publications of the last five years.

Keywords: 2-aminobenzothiazole, biological activity, green chemistry, multicomponent reaction, multistage synthesis, one-pot synthesis.

Benzothiazoles (BTAs) are an important class of bicyclic heterocycles that play a key role in the design of biologically active compounds. At the moment, due to the threat of outbreaks of epidemics associated with the emergence and spread of various viruses (Zika, Lassa, SARS-Cov, etc.), modern research and development in medicinal chemistry and pharmacology based on benzothiazole derivatives have become especially relevant. Recently, the number of publications devoted to the synthesis and study of the pharmacological properties of 2-aminobenzothiazole derivatives has increased significantly. Several review articles are also devoted to this topic. ${ }^{1}$ Molecules with a benzothiazole moiety have a pronounced spectrum of biological activity, exhibiting, along with antiviral, ${ }^{2-5}$ also antimicrobial, ${ }^{6-10}$ anti-inflammatory, ${ }^{10-15}$ antidiabetic, ${ }^{14}$ analgesic, ${ }^{12,13}$ antioxidant, ${ }^{6,14,15}$ antidepressant, ${ }^{16}$ anticonvulsant, ${ }^{17,18}$ antianginal, ${ }^{19}$ antitumor, ${ }^{20,21}$ immunomodulatory effects. BTA derivatives also have anthelmintic, ${ }^{6,7}$ antimalarial, ${ }^{23}$ fungicidal, ${ }^{6,24}$ insecticidal, ${ }^{24,25}$ and herbicidal ${ }^{26}$ effects.

This minireview concisely summarizes the main methods for the preparation of 2-aminobenzothiazole derivatives which include both one-pot and multistep synthesis methods. Their analysis will contribute to the development of targeted synthesis of benzothiazole analogs. $^{27,28}$

In a number of recent studies, the synthesis of BTA derivatives was carried out in the context of the concept of green synthesis. One-pot multicomponent reactions with the participation of 2-aminobenzothiazole are a promising trend in the synthesis of its bioactive derivatives. They have a number of advantages: they are simple in experimental execution, are characterized by high yields of the target products in a relatively short reaction time, and more often proceed in the absence of a solvent. In most reactions, $\mathrm{H}_{2} \mathrm{O}$ is used as a nontoxic and widely available solvent which significantly reduces the cost of the process paving the way for the development of science and technology of the future. ${ }^{29}$ In this case, catalytic reactions are priority, allowing to reduce the impact on the environment.

One example of a green multicomponent synthesis is the three-component reaction of 2-aminobenzothiazole with aromatic aldehydes and 1,3-diketones under microwave irradiation in the absence of a solvent using $\mathrm{Sc}(\mathrm{OTf})_{3}$ as an initiator (Scheme 1). ${ }^{30}$ The method is based on a tandem reaction involving activation of the carbonyl group, the Knoevenagel condensation, nucleophilic addition of an azole followed by intramolecular cyclization to obtain products 1 .

The multicomponent reaction between 2-aminobenzothiazole or its 6-substituted derivatives, indole-3-carbaldehyde, and aryl isocyanides in the presence of a heterogeneous acid catalyst $\mathrm{P}_{2} \mathrm{O}_{5}$ on a $\mathrm{SiO}_{2}$ support leading to 3-amino-2-(indol-3-yl)imidazo[2,1-b][1,3]benzothiazoles 2 is another example. ${ }^{31}$ In this case, the strong dehydrating properties of $\mathrm{P}_{2} \mathrm{O}_{5} / \mathrm{SiO}_{2}$ make it possible to quickly remove $\mathrm{H}_{2} \mathrm{O}$ released as a result of the reaction. The authors used a 
Scheme 1<smiles>Nc1nc2ccccc2s1</smiles><smiles>[R][R]1ccc(C=O)cc1</smiles>

green protocol including environmentally friendly protic solvents $(\mathrm{MeOH}, \mathrm{EtOH})$ and easy catalyst regeneration (washing with hot EtOH and vacuum drying for $1 \mathrm{~h}$, minimal loss of activity with repeated use) (Scheme 2).

Scheme 2<smiles>[R]c1ccc([N+]=[N-])cc1</smiles>

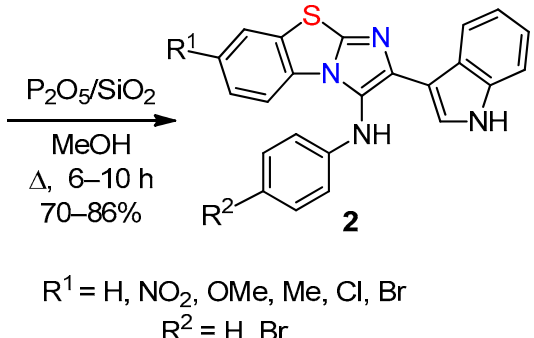

A similar approach was used by Nouri et al..$^{32}$ The $p$-TSAcatalyzed reaction of 2-aminobenzothiazole, arylglyoxal monohydrates, and 2-hydroxy-1,4-naphthoquinone in $\mathrm{H}_{2} \mathrm{O}-$ $\mathrm{Me}_{2} \mathrm{CO}, 2: 1$ was carried out in the presence of $\mathrm{Et}_{3} \mathrm{~N}$ ( $p$-TSA$\left.\mathrm{Et}_{3} \mathrm{~N}, 1: 1\right)$ at room temperature (Scheme 3). Mild reaction conditions, readily available catalysts, ease of isolation, and good yields of compounds 3 (78-84\%) ensure the environmental safety and efficiency of the method.

Scheme 3

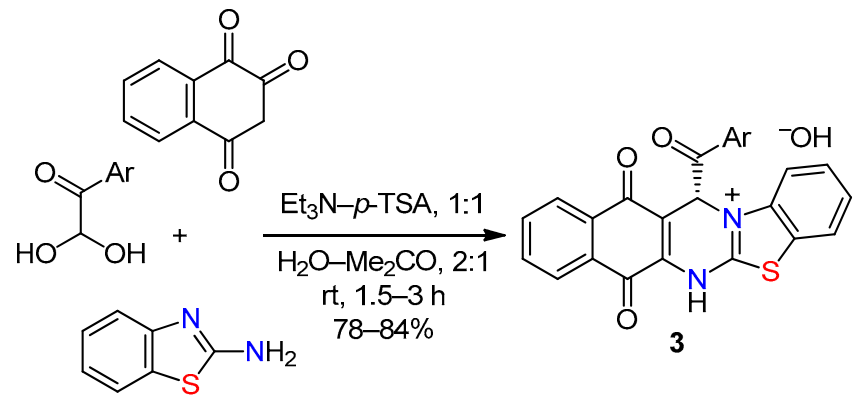

$\mathrm{Ar}=\mathrm{Ph}, 4-\mathrm{ClC}_{6} \mathrm{H}_{4}, 4-\mathrm{FC}_{6} \mathrm{H}_{4}, 4-\mathrm{MeC}_{6} \mathrm{H}_{4}, 3-\mathrm{MeOC}_{6} \mathrm{H}_{4}$, $4-\mathrm{MeOC}_{6} \mathrm{H}_{4}, 3,4-(\mathrm{MeO})_{2} \mathrm{C}_{6} \mathrm{H}_{3}$

A multicomponent technique for constructing spiroheterocycles annulated with biologically active scaffolds was developed by Kumar et al. ${ }^{33}$ Specifically, the pseudofour-component reaction of 2-amino-6-bromo-4-methylbenzothiazole, 4-methoxybenzaldehyde, 4-hydroxycoumarin in the presence of sulfamic acid for $10 \mathrm{~min}$ led to the target product 4 in $93 \%$ yield (Scheme 4). The proposed mechanism involves an acid-catalyzed cascade of the Knoevenagel reaction, condensation of the second aldehyde molecule with 2-aminobenzothiazole, and DielsAlder heterocycloaddition of intermediates. $\mathrm{EtOH}$ also proved to be an effective solvent for the reaction (yield $92 \%$, reaction time $21 \mathrm{~min}$ ). The synthesis of 11 more compounds is described.

Scheme 4<smiles>COc1ccc(C=O)cc1</smiles><smiles>COc1ccc([C@@H]2N3C(=N[C@H](c4ccc(OC)cc4)[C@@]24C(=O)Oc2ccccc2C4=O)Sc2cc(Br)cc(C)c23)cc1</smiles>

Arab-Salmanabadi ${ }^{34}$ synthesized a series of 20 functionalized bisthiazoles 5 and $\mathbf{6}$ in high yields (70-90\%) via the reaction of 2 -aminobenzothiazole with various $\alpha$-halo ketones (bromo ketone, alkyl-2-chloroacetylacetone) in the presence of a sulfide nucleophile (carbon disulfide, aryl isothiocyanate) in an inert solvent. The formation of bisthiazoles involves the addition of carbon disulfide to 2-aminobenzothiazole, condensation of the adduct with $\alpha$-halo ketone, enolization of the resulting intermediate, and cyclization with elimination of $\mathrm{H}_{2} \mathrm{O}$ (Scheme 5).

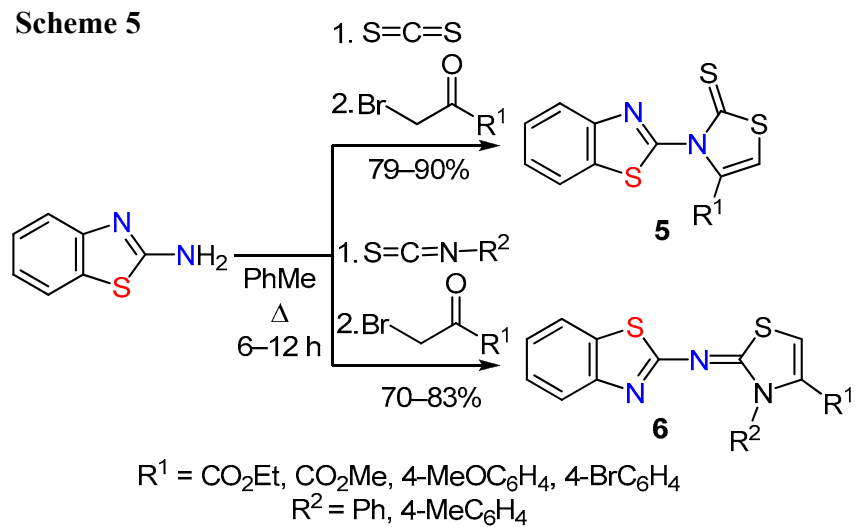

Another method for obtaining the target biologically active 2-aminobenzothiazole derivatives is a sequential multistep synthesis based on commercially available substrates and reagents.

Galochkina et al. ${ }^{2}$ synthesized tricyclic derivatives of imidazo[2,1-b][1,3]benzothiazolones $\mathbf{7}$ in two steps (Scheme 6). In the first step, 2-aminodihydrobenzothiazol7-ones were formed in situ in the reaction of 1,3-diketones with $\mathrm{Br}_{2}$ and thiourea which were then involved in the alkylation reaction with aromatic and heteroaromatic $\alpha$-halo ketones followed by intramolecular cyclization.

Bala et al. ${ }^{10}$ reported on a multistage method for the preparation of a series of benzothiazole-4-formylpyrazoles 


\section{Scheme 6}

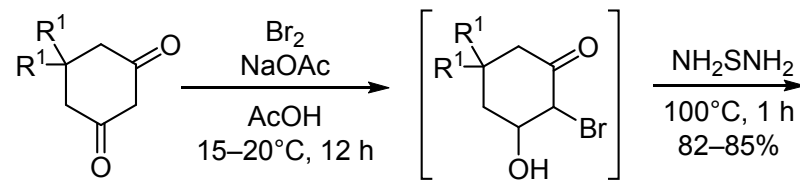

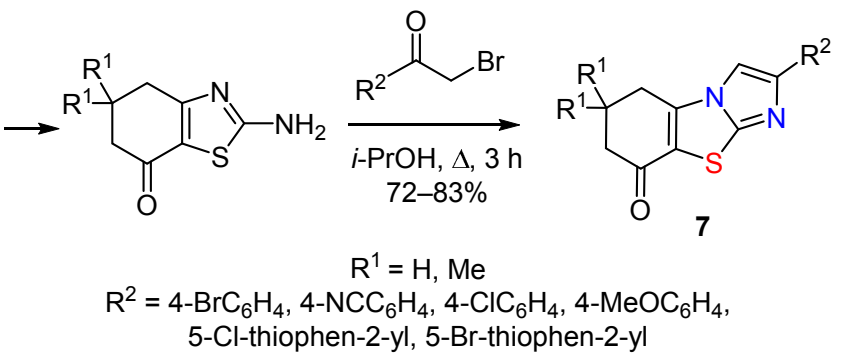

8 (Scheme 7). Oxidative cyclization of aniline derivatives with ammonium thiocyanate and $\mathrm{Br}_{2}$ followed by hydrazinolysis of the corresponding 2-aminobenzothiazoles gave rise to 6-substituted 2-hydrazinylbenzothiazoles, the subsequent condensation of which with aromatic ketones in alcohol leads to benzothiazole hydrazones. Hydrazones were transformed into target products 8 in $65-85 \%$ yields by the Vilsmeier-Haack reaction.

\section{Scheme 7}

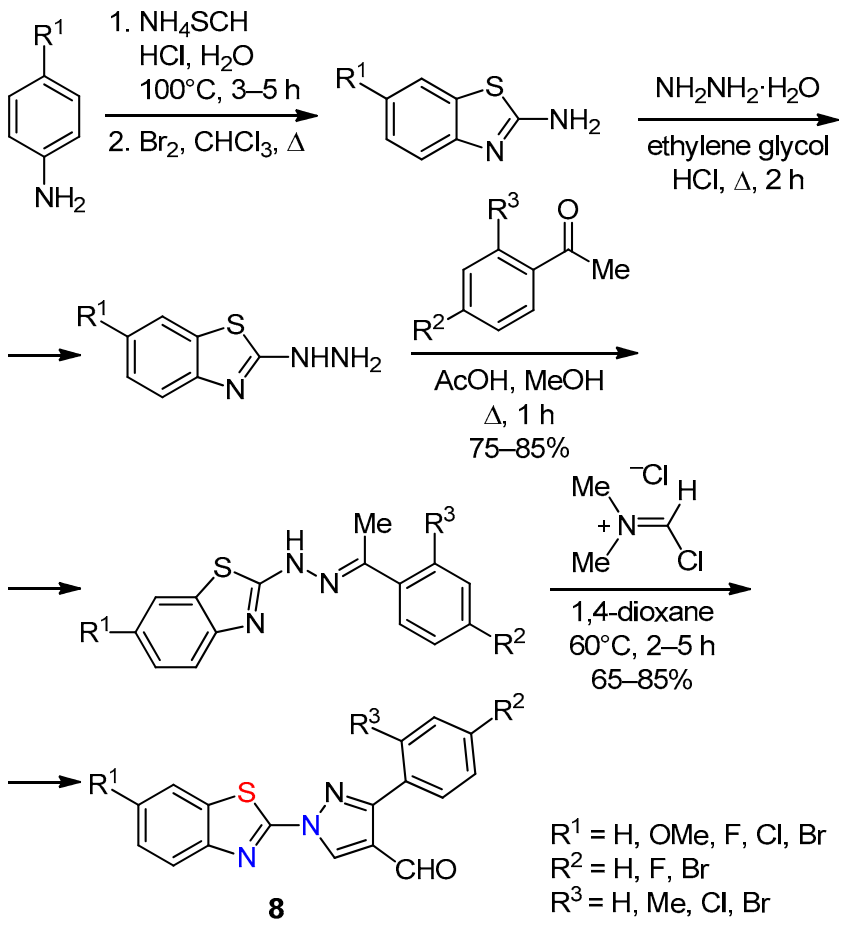

Tarik et al. ${ }^{12}$ showed that 2-mercaptobenzothiazole (captax) or 5-chloro-2-mercaptobenzothiazole can be successfully used to obtain derivatives of 2-hydrazinobenzothiazoles. By heating the mercapto derivatives of benzothiazole in EtOH under reflux and subsequent condensation of the obtained 2-hydrazinobenzothiazole derivatives with oxadiazoles in dry pyridine, a series of unusual 1,2,4-triazoles 9 based on benzothiazol-2-amine were synthesized in good yields (Scheme 8).
Scheme 8<smiles>[R]c1ccc2sc([SiH2]N)nc2c1</smiles>

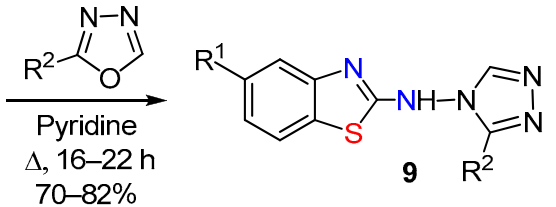

$$
\begin{aligned}
& \mathrm{R}^{1}=\mathrm{H}, \mathrm{Cl} \\
& \mathrm{R}^{2}=\mathrm{PhOCH}_{2}, 4-\mathrm{ClC}_{6} \mathrm{H}_{4} \mathrm{OCH}_{2}, 2,4-\mathrm{Cl}_{2} \mathrm{C}_{6} \mathrm{H}_{3} \mathrm{OCH}_{2} \\
& \text { 2-Me-4- } \mathrm{ClC}_{6} \mathrm{H}_{3} \mathrm{OCH}_{2} \text {, } \mathrm{PhOCH}(\mathrm{Me}), 2,6-\mathrm{Cl}_{2} \mathrm{C}_{6} \mathrm{H}_{3} \mathrm{NHC}_{6} \mathrm{H}_{4} \mathrm{CH}_{2} \text {, } \\
& 4-(i-\mathrm{Bu}) \mathrm{C}_{6} \mathrm{H}_{4} \mathrm{CH}(\mathrm{Me})
\end{aligned}
$$

The formation of new families of biologically active 2,5,6-trisubstituted 2-aminobenzothiazoles was carried out by many researchers. For this purpose, the starting 5,6-substituted derivatives of 2-aminobenzothiazole were synthesized from readily available 3,4-substituted anilines in the presence of $\mathrm{KSCN}$ and $\mathrm{Br}_{2}$. The cyclization was carried out in ice-cold $\mathrm{AcOH}$, the reaction product was then acylated with chloroacetyl chloride. The obtained chloroacetamides were used in reactions with various heterocyclic compounds. ${ }^{5,6,16-18,21,25}$ More than 100 examples are described. Thus, Özkay et al. ${ }^{16}$ synthesized a series of benzothiazole-piperazine derivatives 10 (Scheme 9).

Scheme 9

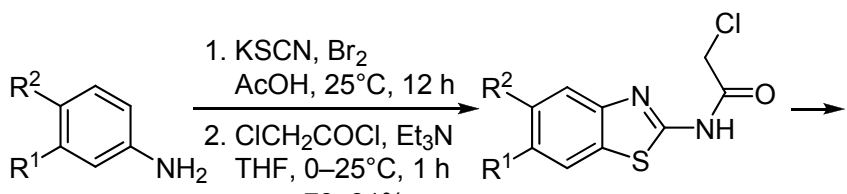
$79-91 \%$

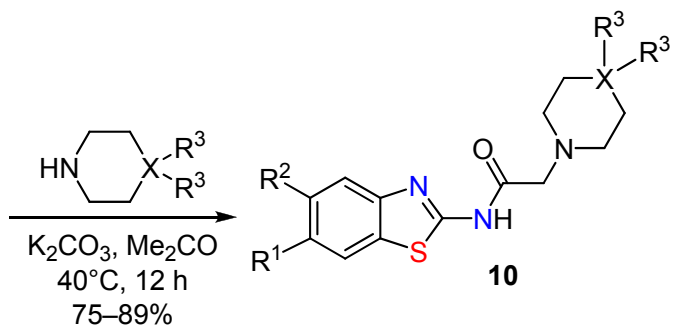

$\mathrm{R}^{1}=\mathrm{H}, \mathrm{Me} ; \mathrm{R}^{2}=\mathrm{Me}, \mathrm{MeO} ; \mathrm{X}=\mathrm{C}, \mathrm{N} ; \mathrm{R}^{3}=\mathrm{H}, \mathrm{Et}, 4-\mathrm{ClC}_{6} \mathrm{H}_{4}$, 4- $\mathrm{FC}_{6} \mathrm{H}_{4} \mathrm{CH}_{2}, 4-\mathrm{MeC}_{6} \mathrm{H}_{4} \mathrm{CH}_{2}, 4-\mathrm{MeOC}_{6} \mathrm{H}_{4} \mathrm{CH}_{2}, 4-\mathrm{F}_{3} \mathrm{CC}_{6} \mathrm{H}_{4} \mathrm{CH}_{2}$, $\left(\mathrm{CH}_{2}\right)_{2} \mathrm{NMe}_{2},\left(\mathrm{CH}_{2}\right)_{3} \mathrm{NMe}_{2}$

A similar approach was used by Amnerkar et al. ${ }^{7}$ The synthesis of amines $\mathbf{1 1}$ and their azomethines (Schiff bases) 12 included the steps of acylation of 6-substituted 2-aminobenzothiazoles with chloroacetyl chloride in dry $\mathrm{PhH}$, cyclization of the acylation product with thiourea in absolute EtOH, and condensation of amines 11 with various aromatic aldehydes (Scheme 10). In this work, 20 compounds were obtained in $58-79 \%$ yields. It was noted that both amines $\mathbf{1 1}$ and bases $\mathbf{1 2}$ exhibited high and in some cases maximum antibacterial, antifungal, and anthelmintic activity. 


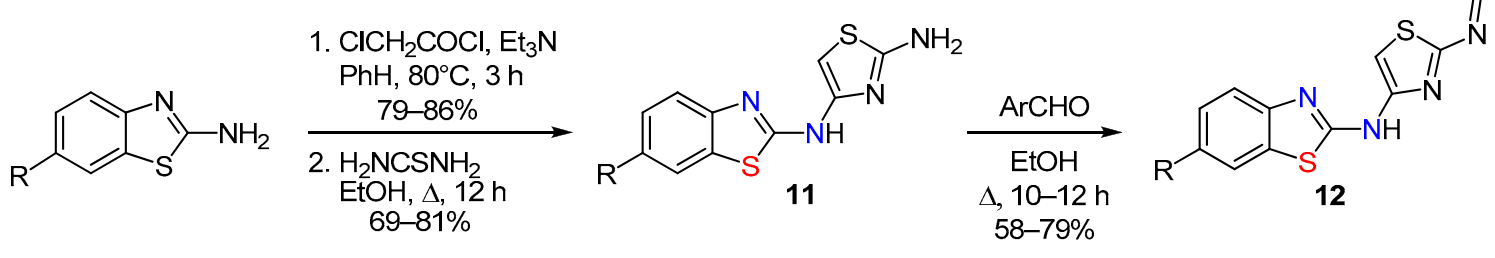

$\mathrm{R}=\mathrm{H}, \mathrm{Me}, \mathrm{F}, \mathrm{OEt} ; \mathrm{Ar}=\mathrm{Ph}, 2-\mathrm{ClC}_{6} \mathrm{H}_{4}, 2-\mathrm{O}_{2} \mathrm{NC}_{6} \mathrm{H}_{4}, 3,4-\mathrm{OMe}_{2} \mathrm{C}_{6} \mathrm{H}_{3}$

Scheme 11

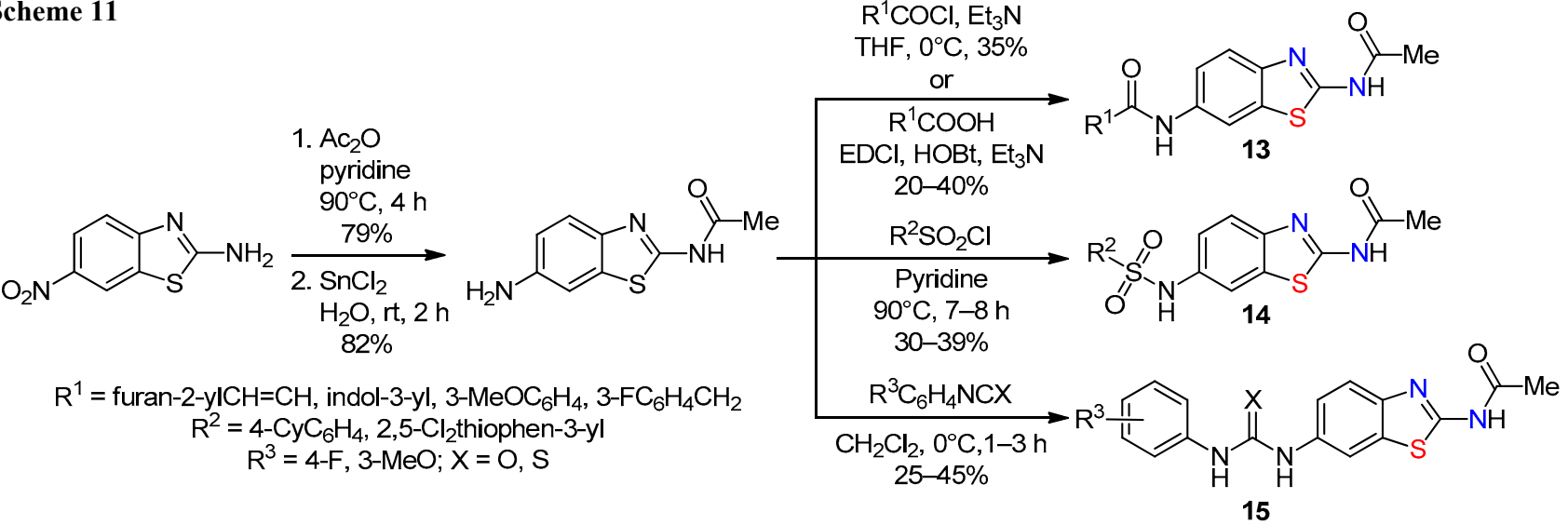

Scheme 12<smiles>[R]N1CCC[C@H]1C(=O)O</smiles>

1. EDCI, DMAP<smiles>[CH2]C[TeH4]</smiles>

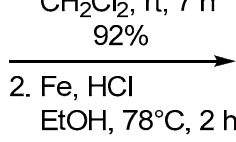

$82 \%$

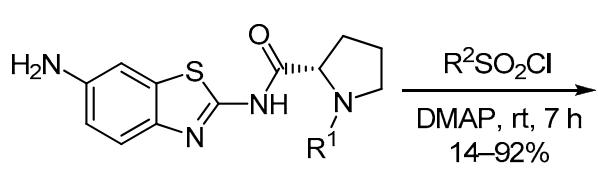

$\mathrm{R}^{1}=\mathrm{Cbz}, \mathrm{Boc}$<smiles>[R]N1CCC[C@H]1C(=O)Nc1nc2ccc(N(S([R])(=O)=O)[SH]([R])([R])=O)cc2s1</smiles>

16
Indian scientists ${ }^{11}$ carried out the synthesis of 6-substituted amide derivatives of 2-aminobenzothiazole 13-15 with high anti-inflammatory activity from 2 -amino6-nitrobenzothiazole in three steps. The formation of compounds 13-15 proceeds via the acylation of 2-amino6-nitrobenzothiazole by the action of $\mathrm{Ac}_{2} \mathrm{O}$ in pyridine, reduction of the nitro group in the acylation product by the action of $\mathrm{SnCl}_{2}$ in $\mathrm{H}_{2} \mathrm{O}$ followed by substitution of the amino group hydrogen atom by acyl, sulfonyl, or carbimide/thiocarbimide groups (Scheme 11).

Liu et al. ${ }^{35}$ synthesized disulfonamide derivatives $\mathbf{1 6}$ also on the basis of 2-amino-6-nitrobenzothiazole. For this, in the first step, proline activated by $\mathrm{EDCl}$ in the presence of DMAP was introduced into the reaction. Subsequent reduction of the nitro group $(\mathrm{Fe} / \mathrm{HCl})$ made it possible to obtain acetamide which then underwent sulfonylation at the amino group (Scheme 12).

Thus, it can be concluded based on the generalization of the available literature data that the easy functionalization of the amino group and benzene ring of 2-aminobenzothiazole makes it possible to classify it as highly reactive pharmacophore synthon for the design of potential biologically active compounds. It should also be noted that, along with multistep methods for the synthesis of 2-aminobenzothiazole derivatives, economical one-pot methods with high synthetic potential which are the basis of modern organic synthesis are being increasingly developed.

\section{References}

1. (a) Agarwal, S.; Gandhi, D.; Kalal, P. Lett. Org. Chem. 2017, 14, 729. (b) Keri, R. S.; Patil, M. R.; Patil, S. A.; Budagumpi, S. Eur. J. Med. Chem. 2015, 89, 207. (c) Rouf, A.; Tanyeli, C. Eur. J. Med. Chem. 2015, 97, 911. (d) Asiri, Y. I.; Alsayari, A.; Muhsinah, A. B.; Mabkhot, Y. N.; Hassan, M. Z. J. Pharm. Pharmacol. 2020, 72, 1459. (e) Liu, X.; Dong, Z.-B. Eur. J. Org. Chem. 2020, 408.

2. Galochkina, A. V.; Bollikanda, R. K.; Zarubaev, V. V.; Tentler, D. G.; Lavrenteva, I. N.; Slita, A. V.; Chirra, N.; Kantevari, S. Arch. Pharm. Chem. Life Sci. 2019, 352, e1800225.

3. Montalvao, S.; Leino, T. O.; Kiuru, P. S.; Lillsunde, K.-E.; Yli-Kauhaluoma, J.; Tammela, P. Arch. Pharm. Chem. Life Sci. 2016, 349, 137.

4. Takamatsu, Y.; Aoki, M.; Bulut, H.; Das, D.; Amano, M.; Sheri, V. R.; Kovari, L. C.; Hayashi, H.; Delino, N. S.; Ghosh, A. K.; Mitsuya, H. Antimicrob. Agents Chemother. 2019, 63, e00372.

5. Wu, H.; Bock, S.; Snitko, M.; Berger, T.; Weidner, T.; Holloway, S.; Kanitz, M.; Diederich, W. E.; Steuber, H.; Walter, C.; Hofmann, D.; Weissbrich, B.; Spannaus, R.; 
Acosta, E. G.; Bartenschlager, R.; Engels, B.; Schirmeister, T.; Bodem, J. Antimicrob. Agents Chemother. 2015, 59, 1100.

6. Yurttaş, L.; Özkay, Y.; Duran, M.; Turan-Zitouni, G.; Özdemir, A.; Cantürk, Z.; Küçükoğlu, K.; Kaplancıklı, Z. A. Phosphorus, Sulfur Silicon Relat. Elem. 2016, 191, 1166.

7. Amnerkar, N. D.; Bhongade, B. A.; Bhusari, K. P. Arabian J. Chem. 2015, 8, 545.

8. Defrenza, I.; Catalano, A.; Carocci, A.; Carrieri, A.; Muraglia, M.; Rosato, A.; Corbo, F.; Franchini C. J. Heterocycl. Chem. 2015, 52, 1705 .

9. Borazjani, N.; Jarrahpour, A.; Rad, J. A.; Mohkam, M.; Behzadi, M.; Ghasemi, Y.; Mirzaeinia, S.; KarbalaeiHeidari, H. R.; Ghanbari, M. M.; Batta, G.; Turos, E. Med. Chem. Res. 2019, 28, 329.

10. Bala, R.; Kumari, P.; Sood, S.; Kumar, V.; Singh, N.; Singh, K. J. Heterocycl. Chem. 2018, 55, 2507.

11. Sadhasivam, G.; Kulanthai, K. J. Chem. Pharm. Res. 2015, 7, 425.

12. Tariq, S.; Alam, O.; Amir, M. Arch. Pharm. Chem. Life Sci. 2018, 351, e1700304.

13. Tariq, S.; Kamboj, P.; Alam, O.; Amir, M. Bioorg. Chem. 2018, 81, 630 .

14. Kumar, V.; Sharma, S.; Husain, A. Int. Curr. Pharm. J. 2015, $4,457$.

15. Ugwu, D. I.; Okoro, U. C.; Ukoha, P. O.; Gupta, A.; Okafor, S. N. J. Enzyme Inhib. Med. Chem. 2018, 33, 405.

16. (a) Özkay, Ü. D.; Kaya, C.; Çevik, U. A.; Can, Ö. D. Molecules 2017, 22, 1490. (b) Özkay, Ü. D.; Can, Ö. D.; Sağlık, B. N.; Çevik, U. A.; Levent, S.; Özkay, Y.; Ilgın, S.; Atl1, Ö. Bioorg. Med. Chem. Lett. 2016, 26, 5387.

17. Liu, D.-C.; Zhang, H.-J.; Jin, C.-M.; Quan, Z.-S. Molecules 2016, 21, 164.

18. (a) Ali, R.; Siddiqui, N. Arch. Pharm. Chem. Life Sci. 2015, 348, 254. (b) Murtuja, S.; Shaquiquzzaman, M.; Amir, M. Lett. Drug Des. Discovery 2018, 15, 398.

19. Harrouche, K.; Renard, J.-F.; Bouider, N.; de Tullio, P.; Goffin, E.; Lebrun, P.; Faury, G.; Pirotte, B.; Khelili, S. Eur. J. Med. Chem. 2016, 115, 352.

20. Ibrahim, D. A.; Lasheen, D. S.; Zaky, M. Y.; Ibrahim, A. W.; Vullo, D.; Ceruso, M.; Supuran, C. T.; El Ella, D. A. A. Bioorg. Med. Chem. 2015, 23, 4989.

21. (a) Hassan, A. Y.; Sarg, M. T.; Hussein, M. J. Heterocycl. Chem. 2019, 56, 1437. (b) Narva, S.; Chitti, S.; Amaroju, S.; Goud, S.; Alvala, M.; Bhattacharjee, D.; Jain, N.; Gowri, C. S. K. V. J. Heterocycl. Chem. 2019, 56, 520. (c) Yang, M.-L.; Zhang, H.; Wang, W.-W.; Wang, X.-J. J. Heterocycl. Chem. 2018, 55, 360. (d) He, J.; Cai, L.; Chen, Y.; He, Y.; Wang, M.; Tang, J.; Guan, H.; Wang, J.; Peng, X. Radiother. Oncol. 2018, 129, 30. (e) Hu, X.; Li, S.; He, Y.; Ai, P.; Wu, S.; Su, Y.; Li, X.; Cai, L.; Peng, X. Oncotarget 2017, 8, 11887.

22. Khan, K. M.; Mesaik, M. A.; Abdalla, O. M.; Rahim, F.; Soomro, S.; Halim, S. A.; Mustafa, G.; Ambreen, N.; Khalid, A. S.; Taha, M.; Perveen, S.; Alam, M. T.; Hameed, A.;
Ul-Haq, Z.; Ullah, H.; Rehman, Z. U.; Siddiqui, R. A.; Voelter, W. Bioorg. Chem. 2016, 64, 21.

23. Sarkar, S.; Siddiqui, A. A.; Saha, S. J.; De, R.; Mazumder, S.; Banerjee, C.; Iqbal, M. S.; Nag, S.; Adhikari, S.; Bandyopadhyay, U. Antimicrob. Agents Chemother. 2016, 60, 4217.

24. Sever, B.; Altıntop, M. D.; Özdemir, A.; Tabanca, N.; Estep, A. S.; Becnel, J. J.; Bloomquist, J. R. Open Chem. 2019, 17, 288.

25. Mao, M.-Z.; Wang, H.-Y.; Wang, W.; Ning, B.-K.; Li, Y.-X.; Xiong, L.-X.; Li, Z.-M. Phosphorus, Sulfur Silicon Relat. Elem. 2017, 192, 42.

26. Che, J.-Y.; Meng, X.-S.; Xu, X.-Y.; Jiang, S.; Gu, Y.-C.; Shi, D.-Q. J. Heterocycl. Chem. 2016, 53, 1494.

27. (a) Grebneva, E. A.; Bolgova, Y. I.; Trofimova, O. M.; Albanov, A. I.; Borodina, T. N. Chem. Heterocycl. Compd. 2019, 55, 762. [Khim. Geterotsikl. Soedin. 2019, 55, 762.] (b) Zhilitskaya, L. V.; Yarosh, N. O.; Shagun, L. G.; Dorofeev, I. A.; Larina, L. I. Chem. Heterocycl. Compd. 2015, 51, 381. [Khim. Geterotsikl. Soedin. 2015, 51, 381.] (c) Zhilitskaya, L. V.; Shagun, L. G.; Dorofeev, I. A.; Yarosh, N. O. Chem. Heterocycl. Compd. 2019, 55, 888. [Khim. Geterotsikl. Soedin. 2019, 55, 888.] (d) Shagun, L. G.; Dorofeev, I. A.; Zhilitskaya, L. V.; Yarosh, N. O.; Larina, L. I. Russ. J. Org. Chem. 2018, 54, 1228. [Zh. Org. Khim. 2018, 54, 1215.] (e) Shagun, L. G.; Dorofeev, I. A.; Zhilitskaya, L. V.; Yarosh, N. O.; Larina, L. I. Russ. J. Org. Chem. 2019, 55, 983. [Zh. Org. Khim. 2019, 55, 1084.] (f) Zhilitskaya, L. V.; Yarosh, N. O.; Shagun, L. G.; Dorofeev, I. A. Russ. J. Gen. Chem. 2020, 90, 1235. [Zh. Obsh. Khim. 2020, 90, 1047.]

28. (a) Yarosh, N. O.; Zhilitskaya, L. V.; Shagun, L. G.; Dorofeev, I. A. Russ. J. Org. Chem. 2020, 56, 833. [Zh. Org. Khim. 2020, 56, 789.] (b) Zhilitskaya, L. V.; Yarosh, N. O.; Shagun, L. G.; Dorofeev, I. A.; Larina, L. I. Mendeleev Commun. 2017, 27, 352. (c) Yarosh, N. O.; Zhilitskaya, L. V.; Shagun, L. G.; Dorofeev, I. A.; Larina, L. I. Russ. J. Org. Chem. 2019, 55, 1071. [Zh. Org. Khim. 2019, 55, 1157.] (d) Lyubchuk, T. V.; Hordiyenko, O. V. Chem. Heterocycl. Compd. 2020, 56, 1. [Khim. Geterotsikl. Soedin. 2020, 56, 1.]

29. (a) Kitanosono, T.; Masuda, K.; Xu, P.; Kobayashi, S. Chem. Rev. 2018, 118, 679. (b) Chen, Z.; Ren, H. Solvents as Reagents in Organic Synthesis: Reactions and Applications; Wu, X.-F., Ed.; Wiley, 2018, p. 1.

30. Gajaganti, S.; Kumari, S.; Kumar, D.; Allam, B. K.; Srivastava, V.; Singh, S. J. Heterocycl. Chem. 2018, 55, 2578.

31. Khan, T.; Yadav, R. J. Heterocycl. Chem. 2019, 56, 11.

32. Nouri, A.; Marjani, A. P.; Khalafy, J. J. Heterocycl. Chem. 2019, 56, 2912.

33. Kumar, M.; Arya, A. K.; George, J.; Arya, K.; Pardasani, R. T. J. Heterocycl. Chem. 2017, 54, 3418.

34. Arab-Salmanabadi, S. J. Heterocycl. Chem. 2017, 54, 3600.

35. Liu, N.; Zhu, S.; Zhang, X.; Yin, X.; Dong, G.; Yao, J.; Miao, Z.; Zhang, W.; Zhang, X.; Sheng. C. Chem. Commun. 2016, 52, 3340. 